
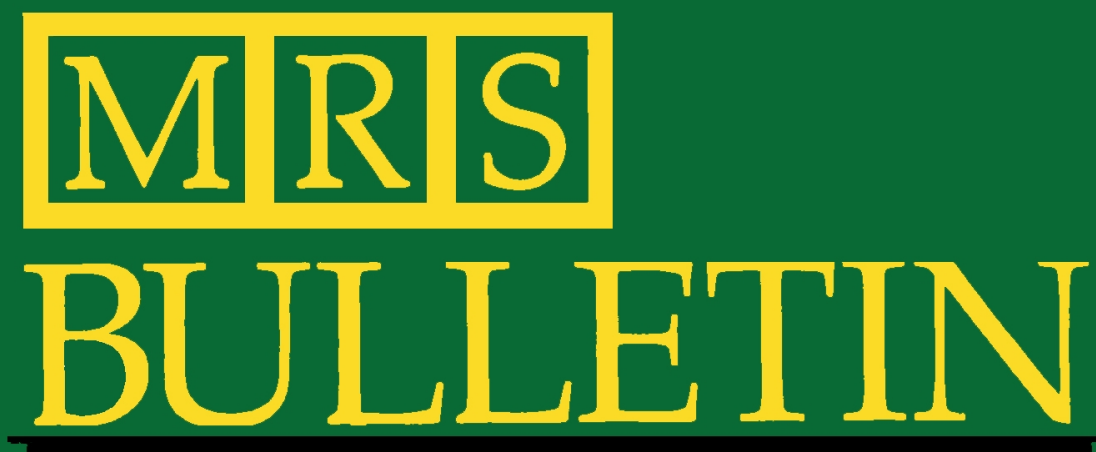

Serving the International Materials Research Community

December 1991, Volume XVI, No. 12

A Publication of the Materials Research Society

Girumine 10

(a) 5

xis 5

\title{
Point Defects
}

\section{Part II}

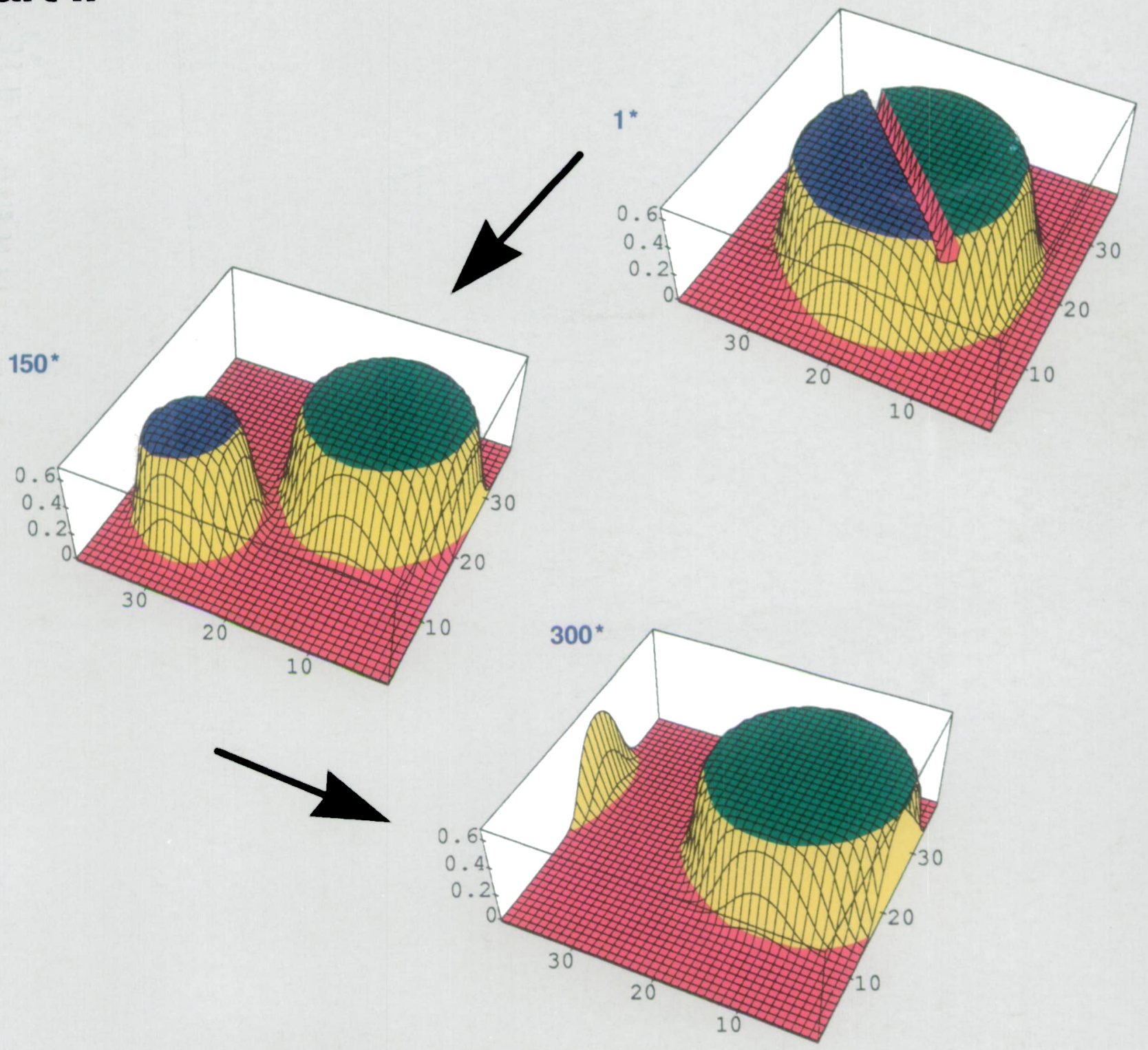

* Fluence in reduced units. 


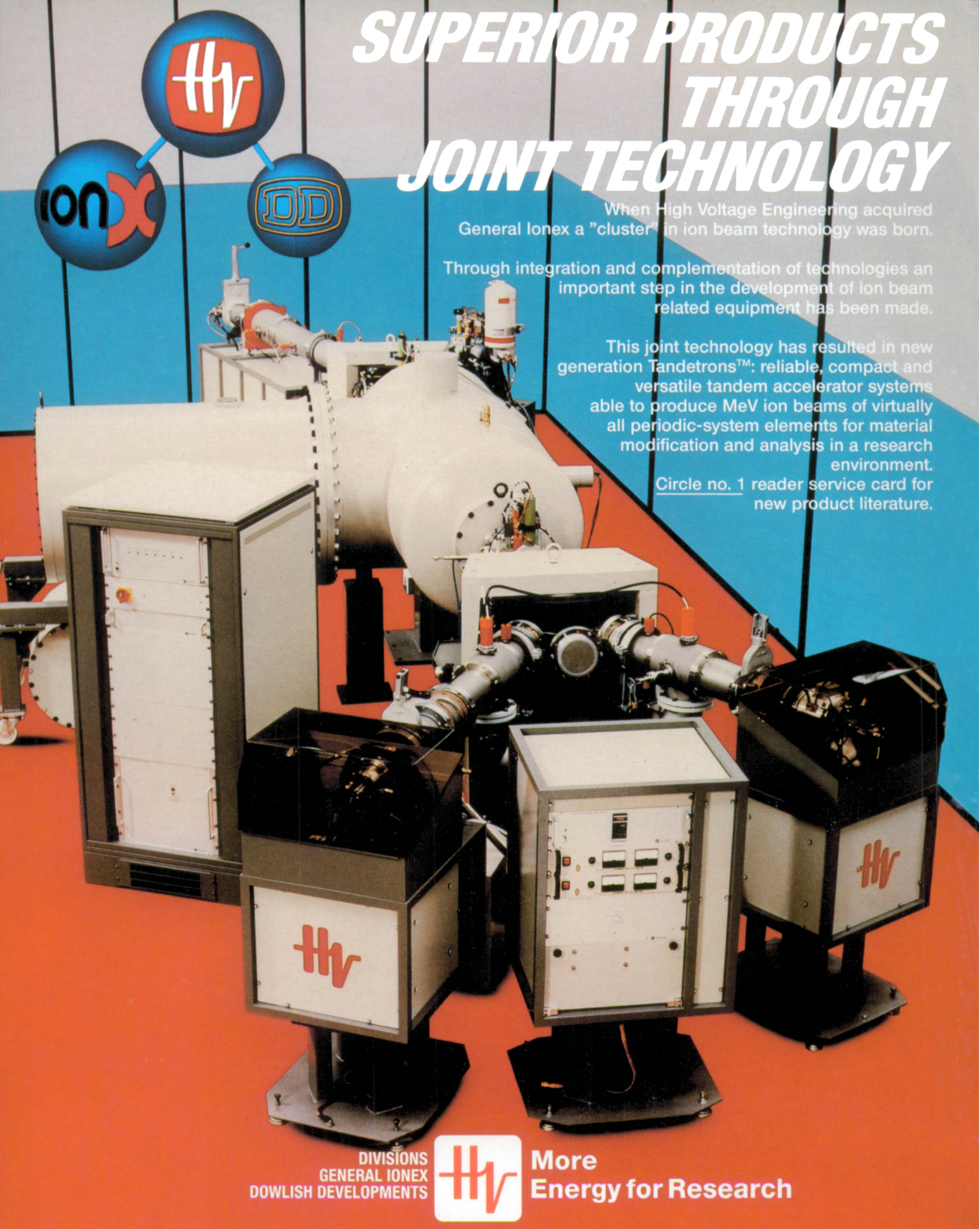

\section{HICH VOLTACE =NCNIN=EING EUROPA IV.}

P.0. Box 99, 3800 AB Amersfoort, The Netherlands, Phone: $(+31) 33-619741$. Fax: $(+31) 33-615291$. Telex: 79100 HIVEC NL 0.1557/S0883769400055214 Published online by Cambridge University Pressmacho, Chuo-ku, Tokyo, 103 Japan, Phone 03-3639-9861, Fax 03-3661-7473 For USA and Canada: HVEC, The Schrafft Center, Suite 602, 529 Main Street, Boston, MA 02129, Phone: (617) 2415000 , Fax: (617) 2415005 


\section{MIRIS}

A Publication of the Materials Research Society Volume XVI, Number 12 ISSN: 0883-7694 CODEN: MRSBEA

\section{POINT DEFECTS} PART II

18 Point Defects in Materials Part II: Applications to Different Materials Problems

D.N. Seidman and D. Shi, Guest Editors

22 Theory of Solid-State Defects

A.M. Stoneham

27 Point Defects and Diffusion in Nonstoichiometric Metal Oxides

R. Dieckmann

33 Antisite Defects and Nonequilibrium Phase Transition in Intermetallics G. Martin and P. Bellon

37 Properties and Defects of Type II Superconductors D. Shi

42 Defect Engineering L. Kimerling

\section{INTERNATIONAL UNION OF MATERIALS RESEARCH SOCIETIES}

48 Australia Establishes Materials Science Committee

\section{MRS NEWS}

49 Nominations Due for 1992 MRS Spring Meeting Graduate Student Awards

\section{DEPARTMENTS}

4 Letter from the President

6 Research/Researchers

12 From Washington

14 Editor's Choice

15 Letters to the Editor

16 Resources

50 Historical Note

52 Book Reviews

54 Classified

56 Advertisers in This Issue

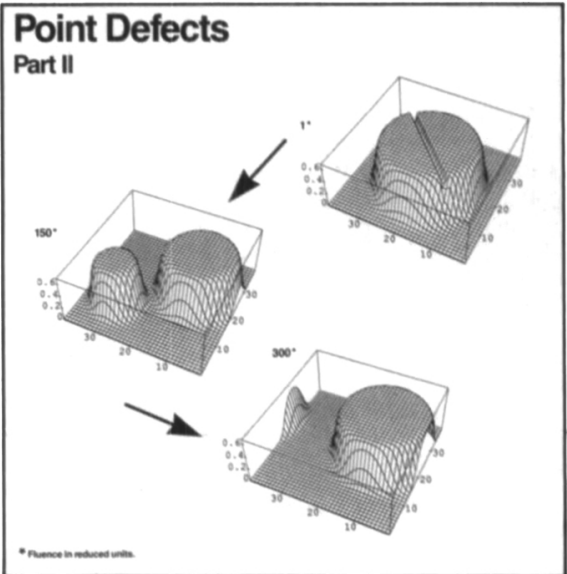

ON THE COVER: An ordered compound is represented by the nonzero value of the longrange order parameter, in equilibrium with the solid solution (red). The precipitate is sheared by an antiphase boundary. As irradiation proceeds, the competition between forced atomic exchanges (replacement collisions) and thermally activated jumps induces an unexpected mechanism of healing the precipitate. As time passes (expressed in reduced units), the solid solution invades the antiphase boundary, and the smaller precipitate then redissolves to the benefit of the larger one. For more information about this topic, see "Antisite Defects and Nonequilibrium Phase Transitions in Intermetallics" by G. Martin and P. Bellon on p. 33. 


\section{About the Materials Research Society}

The Materials Research Society (MRS), a nonprofit scientific association founded in 1973, promotes interdisciplinary goal-oriented basic research on materials of technological importance. Membership in the Society includes more than 10,000 scientists, engineers, and research managers from industrial, government, and university research laboratories in the United States and more than 40 countries.

The Society's interdisciplinary approach differs from that of single-discipline professional societies because it promotes information exchange across the many technical fields touching materials development. MRS sponsors two major international annual meetings encompassing approximately 50 topical symposia, and also sponsors numerous single-topic scientific meetings. The Society recognizes professional and technical excellence, conducts short courses, and fosters technical interaction in local geographic regions through Sections and University Chapters.

MRSparticipates in the international arena of materials research through the International Union of Materials Research Societies (IUMRS). MRS is an affiliate of the American Institute of Physics.

MRS publishes symposium proceedings, MRS Bulletin, Journal of Materials Research, and other publications related to current research activities.

MRS Bulletin (ISSN: 0883-7694) is published 12 times a year by the Materials Research Society, 9800 McKnight Road, Pittsburgh, PA 15237. Application to mail at second class rates has been approved at Pittsburgh, PA and at additional mailing offices. POSTMASTER: Send address changes to MRS Bulletin in care of the Materials Research Society, at the address listed. phone (412) 367-3003; Fax (412) 367-4373

Membership in MRS is $\$ 65$ annually for regular members, $\$ 20$ for students and retired members. Dues include an allocation of $\$ 25$ ( $\$ 15$ for students and retirees) to a subscription to MRS Bulletin. Individua member subscriptions are for personal use only. Non-member subscription rates are $\$ 88$ for one calendar year (12 issues) within the U.S.A. and $\$ 128$ elsewhere. Single copies may be purchased for $\$ 15$ each. Send subscription orders to Subscription Department Materials Research Society, $9800 \mathrm{McKnight}$ Road, Pittsburgh, PA 15237.

MRS Bulletin is included in Current Contents/Physical, Chemical \& Earth Sciences $^{\mathrm{TM}}$ and Research Alert. Back volumes of $M R S$ Bulletin are available in $16 \mathrm{~mm}$ microfilm, $35 \mathrm{~mm}$ microfilm, or $105 \mathrm{~mm}$ microfiche through University Microfilms Inc. 300 North Zeeb Road, Ann Arbor, Michigan 48106 .

\section{MRS BULLETIK}

Publisher

G. A. Oare

Technical Editor

E. L. Fleischer

Assistant Editor

F. M. Wieloch

Copy Editor

D. M. Varner

Art Director

C. Love

Design/Production

W. A. McCalip, J. Probert

CHAIRMAN-EDITORIAL BOARDS

E. N. Kaufmann • Argonne National Laboratory • Argonne, Illinois, USA

\section{INTERNATIONALADVISORY BOARD}

M. Balkanski

University of Pierre and Marie Curie

Paris, France

R. G. Elliman

Australian National University

Canberra, Australia

S. Hsu

Chung Shan Institute of Science

and Technology

Taiwan, China

\section{TECHNICAL EDITORIAL BOARD}

\section{J. C. Bravman}

Stanford University

Stanford, California, USA

C. W. Draper

AT\&T Engineering Research Center

Princeton, New Jersey, USA

F. Y. Fradin

Editorial Assistants

J. Dininny, M. M. Costello

Advertising and Circulation

M. E. Kaufold

Associate Editor-Europe

I. W. Boyd

University College London

Dept of Electronic and

Electrical Engineering

Torrington Place

London WCI E7 JE

United Kingdom

71-387-7050 ext. 3956 or 7304
L. C. Ianniello

Washington, DC, USA

H-D. Li

Tsinghua University

Beijing, China

P. R. Rao

Defence Metallurgical Research

Laboratory

Hyderabad, India
U. S. Department of Energy

\section{G. L. Liedl}

Purdue University

West Lafayette, Indiana, USA

S. Namba

Osaka University

Osaka, Japan
Editorial and Advertising Oftices

9800 McKnight Road

Pittsburgh, PA 15237

Telephone (412)-367-3036

Fax (412) 367-4373

MRS Oflice of Public Affairs

2000 Florida Ave. NW, Third Floor

Washington, DC 20009

Telephone (202) 483-6771

Guest Editors

D. N. Seidman, D. Shi

Special Contributors

K. J. Anderson

Argonne National Laboratory

Argonne, Illinois, USA

\section{MRS BULLETIN PUBLICATIONS SUBCOMMITTEE}

\section{A. Barkatt}

Catholic University of America

Washington, DC

A. J. Hurd

Sandia National Laboratories

Albuquerque, New Mexico

M. R. Libera

Stevens Institute of Technology

Hoboken, New Jersey
R. Roy

Pennsylvania State University University Park, Pennsylvania, USA

T. Sugano

University of Tokyo

Tokyo, Japan

\section{G. J. McCarthy}

North Dakota State University

Fargo, North Dakota

J. M. Phillips

AT\&T Bell Laboratories

Murray Hill, New Jersey

S. M. Prokes

Naval Research Laboratory

Washington, DC

\section{W. H. Sutton}

nited Technologies

Research Center

East Hartford, Connecticut

C. W. White

Oak Ridge National Laboratory

Oak Ridge, Tennessee

\section{MRS EXECUTIVE COMMITTEE}

President

J. B. Roberto

Oak Ridge National Laboratory

First Vice President

and President-Elect

G. S. Cargill II

IBM T. J. Watson Research Center

Second Vice President

S. T. Picraux

Sandia National Laboratories

Secretary
C. M. Jantzen
Westinghouse Savannah River Co.
Treasurer
C. B. Duke
Xerox Research Laboratories

Immediate Past President

R. R. Chianelli

Exxon Research and Engineering

Execulive Direclor

Materials Research Society

John B. Ballance

\section{INTERNATIONAL UNION OF MATERIALS RESEARCH SOCIETIES}

President
R. P. H. Chang
Northwestern University, USA
Tel. (708) $491-3598$; Fax (708) $491-4181$
Vice President

Paul Siffert

Centre de Recherches Nucléaires, France

Tel. (88) 2865 43; Fax (88) 280990

\section{Secretary}

University of New Mexico, USA

Tel. (505) 277-4163; Fax (505) 277-0090
Treasurer

Shigeyuki Sōmiya

Nishi Tokyo University, Japan

Tel. (81) 3417 2866; Fax (81) 34156619

IUMRS ADHERING BODIES

Australian Materials Science Committee (AMSC)

J.S. Williams

Chinese Materials Research Society (C-MRS)

Hengde Li

Materials Research Society (MRS)

James B. Roberto

Materials Research Society of India (MRS-I)

C. N. R. Rao

European Materials Research Society (E-MRS)

Materials Research Society of Japan (MRS-J)

Shigeyuki Sōmiya

Materials Research Society of Korea (MRS-Korea) Min Che Chon

Materials Research Society of Taiwan (MRS-T) Ping-Tien Wu

Mexican Materials Research Society (Mexican MRS) M. J. Yacaman 


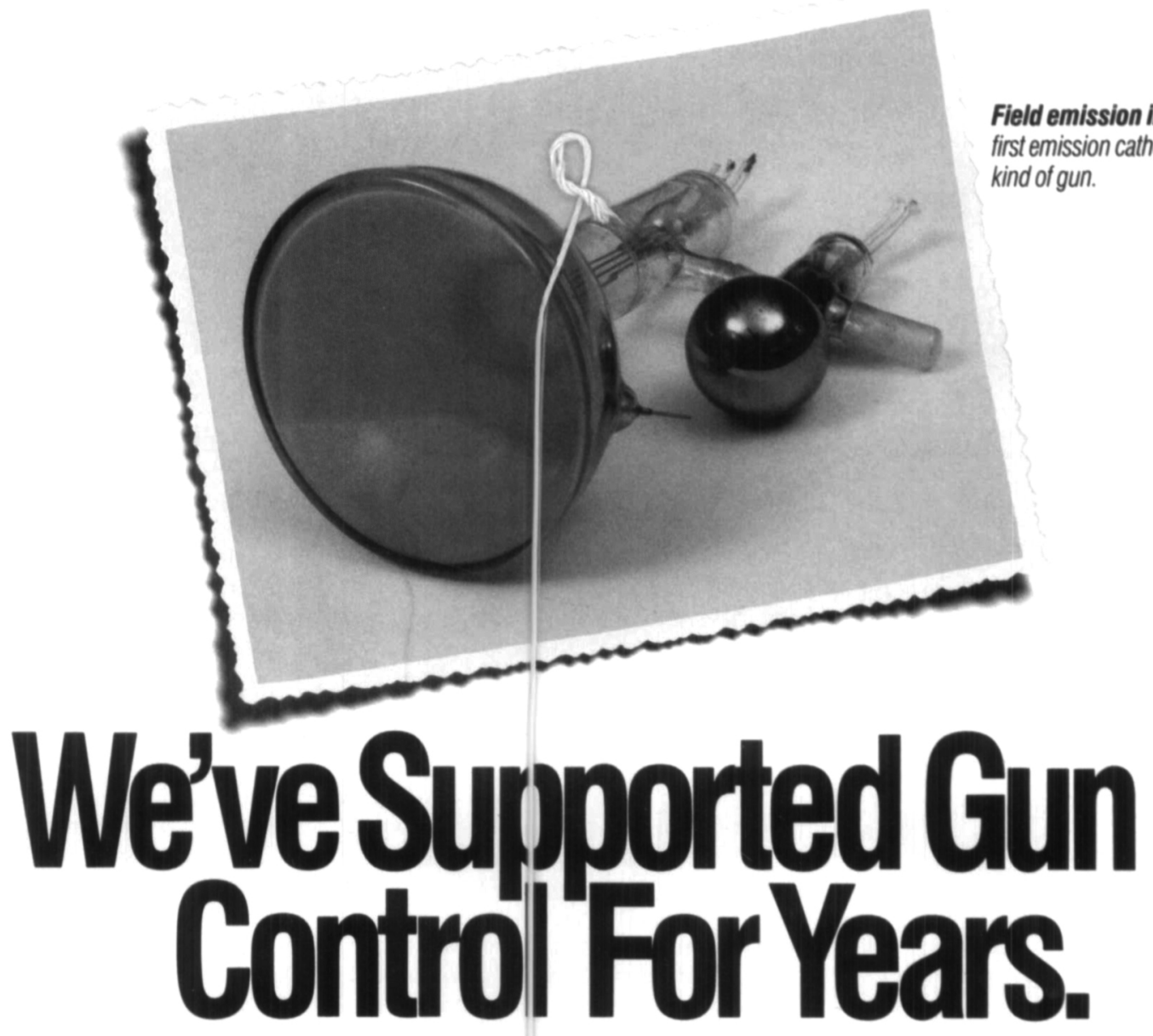

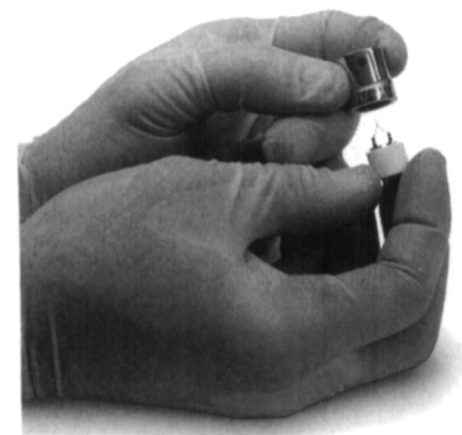

Mounted FEI Schottky cathode with suppressor removed.

FEI bolt-on electrostatic focusing columns can be installed on almost any UHV system.

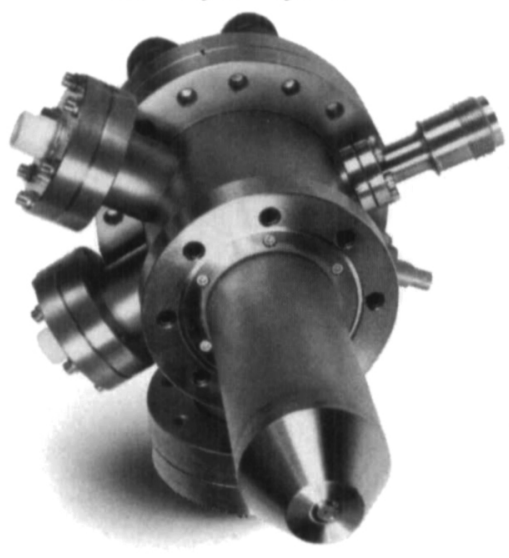

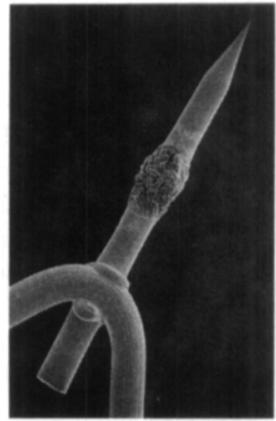

Ip of an an FEI 2-ONW Schottky e nission cathode.

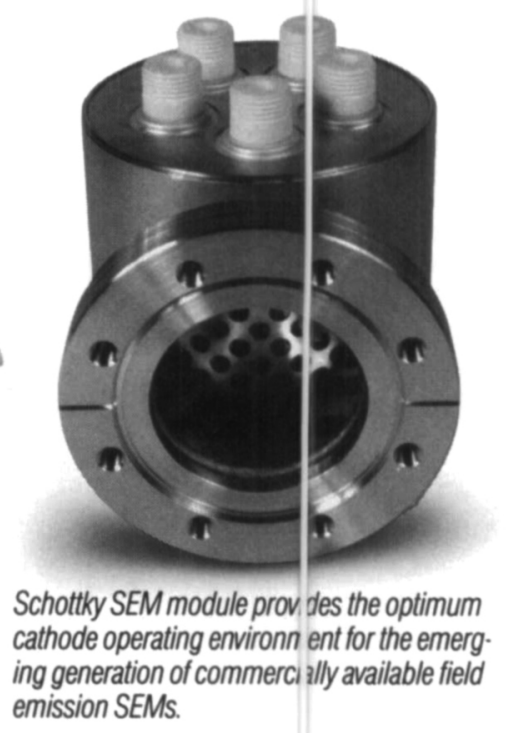

Since 1971, FEl field emission electron gun and cathode compo. nents have provided dramatic beam performance improvements both to individual technologists and com. mercial instrument manufacturers who require nanometer diameter electron beams. Our electron optical designers and applications engineers have extensive experience supplying field emission technology for a diverse range of measurement and fabrication applications. Whether you are building a research instrument or acquiring commercial SEM, Auger or E-beam lithography equipment, discover how FEl can make field emission work for you.

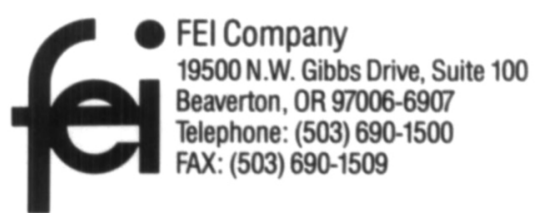

